\title{
Диапазон оценок чехословацких легионеров в русской литературе
}

\section{The Evaluations Range of Czechoslovak Legionaries in Russian Literature}

Нина Владимировна Барковская

(Екатеринбург, Россия)

\section{Абстракт:}

На материале мемуаров и литературных произведений разных лет рассматривается изменение оценок деятельности чехословацких легионеров на Урале. Показана зависимость критериев оценок от господствующей идеологической установки в конкретный период истории России XX в. Делается вывод о противоречивом образе чехословацких легионеров в современной «памяти места». Акцентируется идея «третьего пути» в актуальных интерпретациях событий Гражданской войны на Урале, а также рассматривается попытка показать развитие событий XX века в аспекте «если бы не...» в романе Владимира Каржавина о генерале Войцеховском.

\section{Ключевые слова:}

гражданская война на Урале; чехословацкие легионеры; память места; Войцеховский; произведения о Гражданской войне

\section{Abstract:}

Based on the material of memoirs and literary works of different years, the changes in the assessments of the activity of Czechoslovak legionaries in the Urals are considered. The dependence of the assessment criteria on the prevailing ideological orientation in a particular period of the history of Russia in the twentieth century is shown. The conclusion about the contradictory image of Czechoslovak legionaries in the 
modern "memory of the place" is made. The idea of the "third way" in actual interpretations of the events of the Civil War in the Urals is accentuated, and an attempt to show the development of the events of the twentieth century in the "if not...” aspect in Vladimir Karzhavin's novel about General Wojciechowski also being made.

\section{Key words:}

Russian Civil war at the Urals; Czechoslovak legionaries; memory of the place; Wojciechowski; works about Russian Civil War

В 2018 г. исполняется сто лет событиям, получившим в советское время название «мятежа белочехов». Начиная с 1990-х, именование «белочехи» заменяется на «чехословацкие легионеры» ${ }^{1,2}$. Пересматриваются прежние концепции действий чехословацких войск в России, их роль в инициировании и ходе Гражданской войны ${ }^{3}$. Однако далеко не всё ясно в перипетиях того трагического времени. Евгений Добренко полагает: «..Революция остается живой травмой постсоветской России, частью современности» ${ }^{4}$ Жаркие споры вызывает, например, установка памятников чехословацким воинам. В Екатеринбурге находится один из самых больших мемориалов: на Михайловском кладбище захоронены около 400 легионеров, памятник открыт в 2008 г. на средства Министерства обороны Чешской республики. В Иркутске, Красноярске, Кургане, Нижнеудинске, Миассе, Самаре, Тюмени идея установка памятников вызвала серьезные протесты. Гражданская война явилась таким перекрестком истории, такой точкой бифуркации, когда были возможны разные векторы дальнейшего развития страны, национальная катастрофа разворачивалась в «зоне неопределенности» ${ }^{5}$. В «зоне неопределенности» и ныне остаются в общественном сознании чехословацкие легионеры. Обозначившаяся в Гражданскую войну

1 JURČENKO, V.: Mjatež, kotorogo ne bylo. Rodina, 1994, № 1, s. 28-34.

2 GUSEV, K. V.: K. M. Černov: štrichi $k$ političeskomu portretu (pobedy i poraženija Viktora Černova). Moskva: ROSSPÈN, 1999, s. 205.

3 VALIACHMETOV, A. N.: Novejšaja otečestvennaja istoriografia o čechoslovackom legione $v$ Rossii (1914-1920 gg.). Istoričeskije nauki i archeologia, 2012, № 12 (26), čast’ 2, s. 45-48. <http://scjournal. $\mathrm{ru} / \mathrm{articles} /$ issn_1997-292X_2012_12-2_08.pdf>. [online]. [cit. 1. 7. 2018].

4 DOBRENKO, Je.: Vse, čto vy choteli znat' o Revoljucii? No bojalis'sprosit' u furija Trifonova. Novyj mir, 2017, № 12, s. 184 .

5 VEL'CER, Ch.: Istorija, pamjat' i sovremennost' prošlogo (Pamjat' kak arena političeskoj bor'by). Neprikosnovennyj zapas, 2005, № 2-3, s. 28-35. 
«линия разлома» ${ }^{6}$ тревожит, вот почему продолжается пристрастное всматривание в события вековой давности. Помимо изысканий профессиональных историков, память о прошлом «подпитывают» литература и кино, устные легенды и мифы. Цель данной статьи - проследить изменение оценок деятельности легионеров на Урале, опираясь на историко-публицистические и художественные произведения, в основном - позднесоветского и постсоветского периодов.

Марк Липовецкий полагает, что события Гражданской войны по-прежнему мифологизированы ${ }^{7}$; отмечает ведущую роль мифа и Е.В.Волков в книге «Площадь павших революционеров. Чехословацкий «мятеж» глазами советского художника» ${ }^{8}$. Сложившиеся за годы советской власти медиамифы сегодня активно ремифологизируются. Так, в феврале 2018 г. на берегу городского пруда в Первоуральске любители военной истории воспроизвели бой «красноармейцев» с «белочехами» ${ }^{9}$, аналогичные ролевые игры проводились в г. Михайловске, музей Воздушно-десантных войск в Екатеринбурге организовал в 2017 г. выставку «Город в огне», с мастер-классом по шифрованию и настольной игрой «Временное правительство \& Большевики» ${ }^{10}$.

Морис Хальбвакс вводит понятие «коллективной памяти», чье содержание и шкала оценок задаются приоритетами малой социальной группы, к которой относится индивид ${ }^{11}$. Положительная или негативная оценка деятельности красных и белых определяется тем, что именно оказывается увиденным в конкретных перипетиях Гражданской войны. Тем более это очевидно в случае с чехословацким легионом. Александр и Дина Муратовы (как и большинство «белых» эмигрантов) вспоминают о «белочехах» с неприязнью, ставя им в вину выдачу Колчака красным, вывоз богатой добычи из России, предательство

6 Термин использовал Пьер Байяр: «Линия разлома - след, указывающий место, где, подобно землетрясению, может произойти катастрофа». BAJJAR, P.: «Titanik» utonet. Perevod s fran. Je. Morozovoj. Moskva: Tekst, 2017, s. 187.

7 LIPOVECKIJ, M.: Za čto borolis'? Revolucionnyj narrativ $v$ sovetskich $i$ postsovetskich fil'mach o graždanskoj vojne. Neprikosnovennyj zapas, 2018, № 2 (118), s. 91-111.

8 VOLKOV,Je.V.: Ploščad' pavšich revoljucionerov. Čechoslovackij «mjatež» glazami sovetskogo chudožnika. Čeljabinsk: Kamennyj pojas, 2015.

9 MAR'JANENKO, R.: V Pervoural'ske «krasnoarmejcy» ustroili perestrelku $s$ «beločechami» iz pulemeta Maksima. Jekaterinburg Onlajn. <http://www.e1.ru/news/spool/news_id-53574711.html>. [online]. [cit. 1. 7. 2018].

10 Noč iskusstv - 2017 v Muzeje VDV «Krylataja gvardija». <http://ugvim.ru/afish/nochi-iskusstv-2017v-muzee-vdv-krylataya-gvardiya.html?PAGEN_2=5>. [online]. [cit. 2. 7. 2018].

11 CHALBVAKS, M.: Kollektivnaja i istoričeskaja pamjat'. Moskva: Neprikosnovennyj zapas, 2005, № 2-3, s. 40-41. <http://magazines.russ.ru/nz/2005/2/ha2.html>. [online]. [cit. 1. 7. 2018] 
Белого движения ${ }^{12}$. В постсоветское время возобладала идея национального примирения (героизирован Колчак, но и именами красных командиров по-прежнему называются улицы городов), осознана неразрешимость трагического столкновения «двух правд». Но к чехословацким легионерам все-таки сохраняется настороженное отношение: и белые, и красные - «свои», а вот чехословаки - чужие, «иностранные интервенты». Резко отрицательно характеризует легионеров, например, Егор Яковлев ${ }^{13}$. Столкновение точек зрения продолжается, акценты по-разному расставляются в зависимости от политической и культурной ситуации в стране ${ }^{14}$.

Марк Липовецкий, обратившись к популярным советским фильмам о Гражданской войне, выделяет доминирующие тенденции в изображении событий прошлого. В 1920-1930-е гг. преобладал идеологический критерий оценок, в период «оттепели» главным стал моральный критерий, «этический нарратив», в позднесоветское время в кино о Гражданской войне расцвел жанр «истерна» (вариант вестерна). В постсоветские годы возобладала идея государственности, патриотическая мысль о единстве России, и дореволюционной, и советской, и постсоветской ${ }^{15}$.

Особенность нашего подхода к теме - региональный поворот. Пьер Нора ввел широко используемое понятие «место памяти» ${ }^{16}$. В нашем случае точнее говорить о «памяти места». Возникает вопрос: почему на Урале до сих пор жива память о чехословацких легионерах, с какой идеей связывается их деятельность?

12 MURATOV, A., MURATOVA, D.: Sud'by čechov v Rossii, XX vek. Ot Kieva do Vladivostoka. Praga: Russkaja tradicija, 2012.

13 Cifrovaja istorija: Jegor Jakovlev ob èskalacii Graždanskoj vojny. Youtube. <https://www.youtube. $\mathrm{com} / \mathrm{watch}$ ? $\mathrm{v}=\mathrm{H}_{5} \mathrm{nR}_{2} \mathrm{GXZnEM}>$. [online]. [cit. 1. 7. 2018].

14 Назовем конференции: «Международные отношения в XX-XXI вв.: материалы международной научной конференции в рамках Первых Чемпаловских чтений, посвященных 10о-летию со дня рождения профессора И.Н. Чемпалова (1913-2008)» (Екатеринбург, 2013); «Русский исход как результат национальной катастрофы: к 9о-летию окончания Гражданской войны на европейской территории России» (Москва, 2010) и др., а также многочисленные публикации в специализированных журналах, диссертации, монографии, посвященные данной проблематике; вышел первый том капитального труда «Чешско-словацкий (Чехословацкий) корпус. Документы и материалы» (М., 2013), охватывающий период 1914-1917 гг.

15 LIPOVECKIJ, M.: Za čto borolis'? Revolucionnyj narrativ $v$ sovetskich $i$ postsovetskich fil'mach o graždanskoj vojne. Neprikosnovennyj zapas, 2018, № 2 (118), s. 91-111.

16 NORA, P.: Pokolenije kak mesto pamjati. Perevod s fran. G. Daševskogo. Novoje literaturnoje obozrenije, 1998, № 30, s. 48-72. <http://magazines.russ.ru/nlo/1998/30/>. [online]. [cit. 2. 7 . 2018].; NORA, P.: Vsemirnoje toržestvo pamjati. Neprikosnovennyj zapas, 2005, № 2-3, s. 40-41. <http://magazines.russ.ru/nz/2005/2/nora22.html>. [online]. [cit. 1. 7. 2018]. 
О чехословацком легионе на Урале пишут историки ${ }^{17}$, частично изданы мемуары (Р. Гайды ${ }^{18}$, Ал. Котомкина ${ }^{19}$ ). Ф. О. Велеховский после занятия Екатеринбурга чехословаками в специально изданной брошюре кратко рассказывал, кто такие чехи, освещал их историю, подчеркивал дружественное отношение к России: «У чехословаков нет и не может быть каких-либо завоевательных или других своекорыстных материальных целей» ${ }^{20}$. Завершает брошюру призыв «бороться за свободу и равноправие, против власти белых, красных или черных царьков» 21 .

Заслуживает внимания точка зрения петербургского историка А. М. Захарова $^{22}$. Он полагает, что легионеры не являлись интервентами, поскольку Чешская дружина (создана была в сентябре 1914 г.) имела своей целью войну против Германии, а не вмешательство во внутренние дела России. Когда бывшим пленным разрешено было участвовать в боях, они сражались на германском фронте - общеизвестна героическая битва в июле 1917 под Зборовом, в Галиции. Осенью 1917 был сформирован Чехословацкий корпус. Чехословаки приветствовали русскую революцию, готовы были продолжать войну с Германией.

Обстоятельства изменились с провозглашением Чехословацкой республики - теперь у легионеров преобладало желание вернуться домой. Брестский мир, начало Гражданской войны вмешались в их планы. Чехословацкие легионеры, возвращавшиеся домой через Дальний Восток, согласно соглашению Совнаркома РСФСР и ЧНС (март 1918), частично разоружились.

14 мая на станции Челябинска произошла драка между венгерскими и чешскими солдатами. Был ранен один из чехов и убит венгерский солдат. Представители местного Совета арестовали чехов, потом и офицеров, пошедших на выручку. Тогда Войцеховский отдал приказ освободить

17 VALIACHMETOV, A. N.: Novejšaja otečestvennaja istoriografia o čechoslovackom legione $v$ Rossii (1914-1920 gg.). Istoričeskije nauki i archeologia, 2012, № 12 (26), čast' 2, s. 45-48. <http://scjournal. ru/articles/issn_1997-292X_2012_12-2_08.pdf>. [online]. [cit. 1. 7. 2018].

18 GAIDA, R.: Vospominanija. Fragmenty. Inostrannaja literatura, 2018. № 11. <http://magazines.russ. $\mathrm{ru} /$ inostran/2017/11/vospominaniya-.html>. [online]. [cit. 3. 7. 2018].

19 KOTOMKIN, A. O.: O Čechoslovackich legionerach v Sibiri. 1918-1920. Vospominanija i dokumenty. Pariž, 1930.

20 VELECHOVSKIJ, O. F. Čechoslovaki v Rossii. Jekaterinburg: Izd-vo ČNS (otdelenije dlja Rossii), 1918, s. 37 .

21 Ibid., s. 39.

22 ZACHAROV, A. M.: Slavjanskije vooružennyje formirovanija v Rossii (1917-1920): «vstreča revoljucij» ili «prodannyj korpus»? Istoričeskije, filosofskije, političeskije i juridičeskije nauki, kul'turologija i iskusstvovedenije. Voprosy teorii i praktiki, 2012, № 5-1, s. 76-78. 
арестованных, разогнал Совет. Собственно, так и началось противостояние советской власти и чехословацких легионеров ${ }^{23}$.

25 мая Лев Троцкий приказал: ни один эшелон чехословаков не должен двигаться на восток. От легионеров потребовали полного разоружения. Чехословаки отказались выполнить этот приказ. В мае 1918 г. они свергли советскую власть в Челябинске, 25 июля вошли в Екатеринбург, занимали города вдоль Транссибирской магистрали. В это же время вспыхнули антибольшевистские восстания казачества, рабочих Верх-Нейвинского и Рудянского заводов, потом масштабное восстание в Ижевске и Воткинске.

В августе 1918 г. правительство Франции решило взять под свой контроль действия Чехословацкого корпуса. Не будем прослеживать все дальнейшие события, результат их известен. В июле 1919 чехословаками был оставлен Екатеринбург. 7 февраля 1920 г. на станции Кайтун было подписано перемирие между советским правительством и командованием Чехословацкого корпуса. Исход чехов и словаков из России завершился ${ }^{24}$.

Как эти события отразились в региональной (мемуарной и художественной) литературе? Как шел процесс формирования репутации чехословаков и памяти о них? Приведем примеры из произведений разных лет.

В маленьком рассказе бывшего красноармейца Николая Никитина ${ }^{25}$ «Трава-пышма», входящем в сборник «Вещи о войне» ${ }^{26}$ показан очень редкий женский облик Екатеринбурга зимой 1919 г. (традиционно город металлургов и камнерезов, купцов и золотодобытчиков наделялся маскулинным характером): «А за хитрым ажуром, за окнами плыл мимо туманный город, в белой пыли, точный, сколоченный по чертежу, плыл сдавленный в раме белых гор, замкнутый и развернувшийся широкими улицами в нагорьях, с большими, покатыми, как женские груди, площадями. Плыл в утренних сверкающих рассветах, с белыми соборами, с розовыми, как молодое тело, колокольнями и башнями плыл в пьяной пыли, что неслась с сибирских трактов ветром, и ветер ставил паруса из града...» ${ }^{27}$. Зажиточный город бесстыдно пал в объятия иностранцев: «...город стих на время большевиков, но нынче опять поет город пьяную скверную песню,

23 См., напр.: PRAISMAN, L. G.: Čechoslovackij korpus v 1918 g. Voprosy istorii, 2012, № 5. s. 75-103. Эта же версия излагается в романе В. Каржавина (см. ссылку 52).

24 GOLOVATENKO, A.: Oni šli na vostok. Čechoslovackij korpus v Rossii. Istorija. Izdat. dom «1 sentjabrja», 2008, № 4. <http://his.1september.ru/article.php?ID=200800406>. [online]. [cit. 1. 7 . 2018].

25 Николай Николаевич Никитин (1895-1963) - родился в Петербурге, учился на филологическом факультете Петербургского университета, в 1919-1921 служил в РККА. Позднее входил в группу «Серапионовы братья».

26 NIKITIN, N.: Vešči o vojne. Leningrad: Gos. Izdatel'stvo, 1924, s. 41-58.

27 Ibid., s. 47. 
поет как всегда и в ветер, и в стужу, и этому улыбаются чехи, американцы, колчаковцы, французы и итальянцы. И жадно слушают песню на расписных гладких улицах гладкие и сытые особняки» ${ }^{28}$. А начинался этот, по мнению автора-красноармейца, последний разгул на краю бездны, еще жарким летом, когда за городом зрела земляника, «и от ягодного духу зрели спелые бабьи губы... В духу, в ягоде, истомленные июлем, бабы ложились в кустах. В кусты же приходили серые чехи, с серыми и жесткими, что лесной лен, усами, чтобы томить сладостью баб» ${ }^{29}$. Вероятно, столь вольное поведение можно было бы объяснить нехваткой мужчин, призванных на войну с Германией, но, скорей всего, это выражение авторской мысли о порочности буржуазии и всего уклада дореволюционной России ${ }^{30}$. В конце рассказа Никитин сообщает, что в нищем домике на окраине города заседает партийная ячейка во главе с большевиком Антоном Черняком, и последняя фраза говорит о победе над врагами революции: «В июле пришли красные. И земляника, и пышма ${ }^{31}$ были этим июлем прекрасны» 32 .

Противоположную оценку облику города, в котором установилась Советская власть, дает современный автор Арсен Титов в романе «Екатеринбург: восемнадцатый» (2014). Он рисует зимний город, в котором оказался, после ранений и тифа, Борис Норин, офицер-артиллерист бывшего казачьего корпуса. Норин с отвращением смотрит на родной город и не узнает его: такая грязь и запустение. Приведем одну деталь, характеризующую облик города, занятого красными. Комендант переполненного, зловонного и загаженного вокзала, где царила полная неразбериха, сообщил, что в городе вместо необходимых трехсот тридцати золотарей работают только тридцать - и весной город просто утонет в нечистотах. На привокзальной площади Норину встретился единственный

28 Ibid., s. 48.

29 Ibid., s. 41.

30 Хотя, как известно, семейных союзов много возникло: еще до революции Карел Крамарж обвенчался с Н.Н. Абрикосовой, единственной наследницей промышленника Н. Н. Хлудова; преподаватель физкультуры в мужской гимназии Екатеринбурга Матей Немец женился на дочери пивовара Анне Тесарж, Радола Гайда женился на Е.Н. Пермяковой, полковник К. Гусарек - на А. А. Прокурорской, записи об этих браках составил секретарь консульства В. Чех, сам женившийся на Е. В. Поповой, зарегистрированы также многие другие браки. См.: DMITRIJEV, N. I.: Čechoslovackije legionery na Urale. Materialy konferencii «Graždanskaja vojna na vostoke Rossii». Perm', 2008. <http://www.permgaspi.ru/publikatsii/konferentsii/grazhdanskayavojna-na-vostoke-rossii/n-i-dmitriev-chehoslovatskie-legionery-na-urale.html>. [online]. [cit. 1. 7 . 2018]., а также ŠORIN, A.: Jekaterinburg glazami legionerov. <http://www.oblgazeta.ru/society/ 14154/>. [online]. [cit. 1. 7. 2018].

31 Пышма́ (Руšma) - название реки и расположенных на ней городов и поселков, напр., Верхняя Пышма; «трава, которая цветет», называется пи́жма (ріžma).

32 NIKITIN, N.: Vešči o vojne. Leningrad: Gos. Izdatel'stvo, 1924, s. 58. 
водовоз с дырявой бочкой. Грязь увидел Норин и в батюшкином доме, куда были поселены квартиранты: они «начисто все запоганили» ${ }^{33}$. А вот зима следующего года, уже в описании Никитина, когда в городе закрепились чехословаки: «Этот год на суровом небе было прекрасное вышито солнце. И дни в городе стояли каленые. В пожарных бадьях у рынка мерзла вода на морозе. А метлы - торчками - в бадьях, горели хрустально» ${ }^{34}$. Хрусталь и нечистоты контраст говорит не в пользу режима красных.

Далибор Ваха ${ }^{35}$ приводит сведения о широкой культурной деятельности чехословаков, в том числе и в Екатеринбурге, проводимой Информационно-просветительским отделом (председатель Йозеф Кудела): журнал «Чехословенске беседы», иллюстрированная газета, сатирический журнал «Качели», симфонический оркестр под руководством Рудольфа Карела, театр с режиссером Йозефом Йеничеком, парады и смотры, занятия спортом (сокольское движение успешно пропагандировал еще до 1914 Матей Немец ${ }^{36}$ ). Вызывала интерес чехословаков деятельность Уральского общества любителей естествознания (УОЛЕ), о чем свидетельствуют записи в книге посетителей (Общество было открыто в 1870 г., закрыто в 1929 по решению органов советской власти, ныне восстановлено).

На бытовом уровне, в повседневном общении, у легионеров не проявлялась установка на враждебность по отношению к «красным» или «белым». А. М. Кручинин приводит следующий факт: прапорщик Матей Немец вел свой батальон от Полдневой без карты, по памяти. Будучи в 1910-1914 годах учителем сокольской гимнастики в Екатеринбургских мужской гимназии и реальном училище, он часто бывал в этих лесах на охоте. Колонна чехов подходила к реке Чусовой, когда из леса выскочил молоденький красноармеец с белым носовым платком на штыке винтовки. Увидев М. Немеца, он закричал: «Матвей Францевич, здравствуйте!». Оказалось, что это Смирнов - бывший ученик из

33 TITOV, A.: fekatrinburg: vosemnadcatyj. Ural, 2014, № 11, s. 17.

34 NIKITIN, N.: Vešči o vojne. Leningrad: Gos. Izdatel'stvo, 1924, s. 41.

35 VACHA, D.: Dosug češskich legionerov v Rossii i na puti domoj v 1919-1920-ch gg. Rossica, 2012, № 1, s. 55-86. <http://www.ceeol.com/search/article-detail?id=577683>. [online]. [cit. 1. 7. 2018].

36 Йозеф Иржи Швец в своем «Дневнике» писал, что в Россию в свое время приехало примерно 200 учителей физкультуры из Чехии. Среди них - будущий генерал Матей Немец, автор книги о С.Н. Войцеховском. М. Немец работал в Екатеринбурге четыре года, занимаясь преподаванием гимнастики в мужской классической гимназии и реальном училище. М.Немец стал одним из зачинателей физкультурного движения в среде российской молодежи. Когда в сентябре 1914 г. Матей Немец уехал добровольцем в Чешскую дружину, то в знак признания заслуг за ним были до конца войны сохранены преподавательское место и жалованье. Цит. по: Iz Čechii na kraj sveta. Žizn' čechoslovackich legionerov v Rossii $i$ Ekaterinburge v 1914-1920 gg. i jeje otraženije v češskom iskusstve: Katalog vystavki. Jekaterinburg, 2009, s. 11. 
реального училища. Он был принят в чешскую роту и пошел с ней в наступление на Екатеринбург ${ }^{37}$. Леонид Юзефович в документальном романе «Зимняя дорога» (о якутском противостоянии генерала А.Н.Пепеляева и анархиста И. Я. Строда) приводит случай помощи белому офицеру. После падения Омска белые и беженцы в тридцатиградусные морозы пытались эвакуироваться на восток (Великий Сибирский Ледяной поход). За Красноярском магистраль была в руках красных, пропускали только чехословацкие эшелоны. Метавшегося в тифозном бреду Пепеляева подобрал и взял к себе в вагон незнакомый чешский офицер ${ }^{38}$.

Еще один любопытный факт. Почти тем же маршрутом, что и легионеры, ехали под эгидой Красного Креста восемьсот детей, вывезенных из голодного Петрограда на Урал. В связи с начавшейся Гражданской войной они совершили кругосветное путешествие, вернувшись в Петроград через Владивосток, Китай, США, Францию. Книга Владимира Липовецкого «Ковчег детей» построена на воспоминаниях участников этого путешествия. Как и чехословаков, представителей Красного Креста не считала своими ни одна из воюющих сторон: «...к нам относится с предубеждением не только гражданское население, но и русская армия. И красные, и белые одинаково обвиняют нас в помощи противной стороне. [...] Нас подозревают в коварстве и тайных замыслах. Любая ошибка или упущение возводится в степень» ${ }^{39}$. Видимо, тут также сказывался стереотип подозрительного отношения к «чужим». Среди сопровождавших детей взрослых был и чех Вячеслав Вихра. Однажды поезд остановили чешские солдаты (до этого вагоны обыскивали казаки), начали обыск, не обращая внимания на слова воспитательницы, что здесь только дети. Но Вихра сказал что-то по-чешски, солдаты отдали честь и вышли, оставив детей из красного Петрограда в покое ${ }^{40}$.

А. И. Медведев, екатеринбургский рабочий, красноармеец и писатель, воспоминает о борьбе с «белочехами, поднявшими мятеж по приказу своих генералов, купленных империалистами Антанты». Но, судя по его же воспоминаниям, по большей части сражаться красным приходилось с казаками-дутовцами и эсерами. В Челябинске бойцы подружились с чехами, жившими в вагонах тут же, на станции, даже обедали в их столовой. По приказу чешского офицера

37 KRUČININ, A. M.: Padenije krasnogo Jekaterinburga: Vojenno-istoričeskij očerk o sobytijach na Srednem Urale $i v$ Zaural'je $s 13$ ijulja po 12 avgusta 1918 goda. Jekaterinburg: Belaja Rossija, 2005, s. 31-32.

38 JUZEFOVIČ, L.: Zimnjaja doroga. General A. N. Pepeljajev i anarchist I. Fa. Strod v Fakutii 1922-1923. Dokumental'nyj roman. Moskva: Redakcija Jeleny Šubinoj; AST, 2016, s. 29.

39 LIPOVECKIJ, V.: Kovčeg detej, ili Neverojatnaja odisseja. Vladivostok: Rubež, 2011, s. 166-167.

40 Ibid., s. 43. 
красные были арестованы. Но красноармейцы сумели убежать, явно при попустительстве караулившего их солдата-чеха ${ }^{41}$.

В очерке, опубликованном в журнале «Уральский следопыт» № 7 за 1957 г. (номер вышел под девизом: «40-летие со дня освобождения от белогвардейцев и иностранных интервентов, пытавшихся утвердить власть адмирала-палача Колчака»), в воспоминаниях А. Гундорина, генерал-майора в отставке, сообщается, что уходили белочехи практически без боев - и это согласуется с той версией, что легионеры преследовали свои цели, вовсе не стремясь оккупировать Урал в качестве интервентов ${ }^{42}$.

Всё чаще деятельность чехословацких легионеров расценивается как «третий путь». А.М. Захаров пишет: «...представить себе солдата Чехословацкого корпуса или польских легионов, одержимого „белой“ идеей с её пропагандой „единонеделимости“ России, как-то затруднительно» ${ }^{43}$. По мнению исследователя, «польские, чешские, словацкие и югославянские волонтеры белых сил вдохновлялись, как это ни парадоксально, тоже вполне революционными идеями. Только их революция должна была быть национально-освободительной в первую очередь и славянской - во вторую». Прослеживая историю чехословацкого легиона, А. М. Захаров приходит к выводу: «К концу Гражданской войны стало очевидно: две разные революции, встретившись на территории России, разошлись - каждая своим путем...» ${ }^{44}$.

Антиимперские чувства, любовь к родной земле, желание видеть её независимой и демократичной, двигавшие чехословацкими легионерами, совпали на некоторый период с попыткой создания региональных автономий, в частности, Уральской. Г. Д. Селянинова пишет: «19 августа в Екатеринбурге было сформировано Временное областное правительство Урала [...] уже в августе 1918 г. на территориях, оставленных большевиками, образовалось 19 самостоятельных региональных правительств [...]. Создание таких правительств в годы Гражданской войны было попыткой российской интеллигенции учредить демократические структуры власти, основываясь на идее <третьего пути〉. Идея 〈третьего пути〉 воплотилась в стремлении правительств занять

41 MEDVEDEV, A.: Po dolinam i po vzgorjam. Izd. 4-je. Sverdlovsk: Sredne-Ural. kn. izd-vo, 1964, s. 88-89.

42 GUNDORIN, A. Kak osvobodili fekaterinburg. Ural'skij sledopyt, 1957, № 7, s. 28-32.

43 ZACHAROV, A. M.: Slavjanskije vooružennyje formirovanija v Rossii (1917-192o): «vstreča revoljucij» ili «prodannyj korpus»? Istoričeskije, filosofskije, političeskije i juridičeskije nauki, kul'turologija i iskusstvovedenije. Voprosy teorii i praktiki, 2012, № 5-1, s. 77 .

44 Ibid., s. 78. 
промежуточную позицию между диктатурой пролетариата и диктатурой буржуазии и на практике осуществить внеклассовое 〈народовластие〉» ${ }^{45}$.

Непосредственный участник уральского областного правительства Л.А.Кроль вспоминает ситуацию: «...если бы удалось избавить Урал от двух таких прелестей, как Омск и Самара, было бы очень хорошо» ${ }^{46}$, поскольку «для горнозаводского Урала совершенно не подойдет ни политика Самары, ни политика Омска» ${ }^{47}$. Временным областным правительством Урала провозглашались демократические принципы ${ }^{48}$, а главной целью - сохранение уральской промышленности. Разумеется, это региональное правительство, обвиненное в сепаратизме, просуществовало ровно то время, пока военная власть была у чехословаков. (В 1993 г., опять-таки не по политическим, а по экономическим причинам, губернатор Э. Россель попытался снова осуществить идею Уральской республики ${ }^{49,50}$ ).

В годы Гражданской войны были и другие проекты областных правительств. Л. Юзефович в романе «Зимняя дорога» повествует о мечте генерала Пепеляева заключить мир с красными на основе автономии Сибири. Якутскую эпопею Пепеляева Юзефович назвал последней в истории Гражданской войны социальной утопией ${ }^{51}$.

Владимир Каржавин в романе о Войцеховском упоминает план Врангеля сделать Крым «опытным полем», на котором можно было бы создать модель России, альтернативную «России большевистской». Врангель надеялся на

45 SELJANINOVA, G.D.: Intelligencija $i$ «tretij put» $v$ Graždanskoj vojne na Urale. <http://www. permgaspi.ru/publikatsii/konferentsii/grazhdanskaya-vojna-na-vostoke-rossii/g-d-selyaninovaintelligentsiya-i-tretij-put-v-grazhdanskoj-vojne-na-urale.html>. [online]. [cit. 2. 7. 2018].

46 KROL', L. A.: Za tri goda. Vospominanija, vpečatlenija i vstreči. Vladivostok: Tip. «Svobodnaja Rossija», 1921, S. 71.

47 Ibid., s. 64 .

48 Ibid., s. 73 .

49 KOCHANOVSKIJ, A. A.: «Pravitel'stvo trech ujezdov» kak opyt ural'skoj gosudarstvennosti perioda načala graždanskoj vojny. Dokument. Archiv. Istorija. Sovremennost': sbornik naučnych trudov, Jekaterinburg: izd-vo Ural. un-ta, 2017, vypusk 17, s. 21-29. <http://elar.urfu.ru/bitstream/10995/ 43675/1/978-5-7996-1955-8_2016_25.pdf>. [online]. [cit. 4. 7. 2018].

50 О причинах нежизнеспособности опыта областной автономии см.: SOLOVJJEVA, T. V.: Ideja Uralskoj respubliki v uslovijach revolucionnych potrjasenij. 1917 god v Rossii: socialističeskaja ideja, revoljucionnaja mifologija i praktika: sbornik naučnych trudov, Jekaterinburg: izd-vo Ural. un-ta, 2016, s. 287-298. <http://elar.urfu.ru/bitstream/10995/43675/1/978-5-7996-1955-8_2016_25.pdf>. [online]. [cit. 1. 7. 2018]. Видимо, статус горного города («государства в государстве»), полученный Екатеринбургом в 1831 г., актуализируется в памяти в соответствующих условиях.

51 JUZEFOVIČ, L.: Zimnjaja doroga. General A. N. Pepeljajev i anarchist I. Fa. Strod v Fakutii 1922-1923. Dokumental'nyj roman. Moskva: Redakcija Jeleny Šubinoj; AST, 2016, s. 112, 113. 
соглашение с атаманами Дона, Кубани, Терека и Астрахани, рассчитывал на поддержку Забайкальского казачьего войска; важным моментом программы Врангеля был «Приказ о земле», предусматривающий закрепление земли за крестьянами и свободу местного самоуправления ${ }^{52}$. Идеи Врангеля понравились сибирскому атаману Семенову: «...надо по примеру Крыма создавать здесь, на местах, что-то вроде автономий» ${ }^{53}$.

Почвой для активизации попыток автономии послужил своего рода географический «перевертыш», отмеченный Юзефовичем: надежды возлагались не на столицу и центральные районы, а на восток, т. е. центр и периферия поменялись местами. Линия фронта проходила вдоль Транссиба, пролегающего через отдаленные регионы внутри страны. Такая инверсия, выворачивание наизнанку внутреннего и внешнего, западного и восточного, «своего» и «чужого», ломаная траектория линии боев, смещение (эксцентрика) фронтира приводили к тому, что высвечивались те территории, которым ранее не придавалось решающего значения.

Особую роль на «перекрестках истории» играют фигуры посредников, «медиаторов», снимающих оппозицию «своих» и «чужих». В логике бинарных оппозиций нельзя рассмотреть тех участников чехословацкого легиона, для которых Урал не был чужой землей. Таковы уже упоминавшийся Матей Немец или Платон Деев, закончивший в свое время Художественно-промышленную школу в Екатеринбурге, служивший в чехословацком легионе, с 1923 г. проживавший в Праге, подготовивший уникальную книгу «Художники-легионеры».

Одной из ярких личностей являлся Сергей Николаевич Войцеховский. В Беларуси в 2015 г. был показан документальный фильм Анжелики Новиковой «Сергей Войцеховский. Генерал без родины». Название призвано подчеркнуть трагическую судьбу Войцеховского, умершего в лагере под Тайшетом в 1951 г. в тех же местах, где некогда ему пришлось разделить с колчаковцами Великий Сибирский Ледяной поход. Однако название фильма кажется не очень удачным в силу двусмысленности: родина ли отказалась от генерала или генералу не дорога была идея родины?

В романе Каржавина «Дважды генерал и Чешская мафия» Войцеховский представлен именно как «герой места», хотя ему, в силу профессии и исторических перипетий, пришлось постоянно переезжать, менять страны, много времени проводить в дороге. Важнейшее качество Войцеховского - верность присяге, долгу и товарищам по оружию. Паролем при встречах однополчан служит топоним «Зборов». При встрече с Кругловым в Сибири Войцеховский

52 KARŽAVIN, V.: Dvaždy general i Češskaja mafija. Ural, 2017, № 2, s. 36.

53 Ibid., s. 36-37. 
напоминает ему о высоте 862 в Карпатах, и тот поддерживает тост: «Забудешь такое... За Россию!». Сопровождать почти безоружный чехословацкий корпус во Владивосток (вместо того, чтобы пробираться на Дон в Добровольческую армию) Войцеховский согласился именно потому, что не мог бросить боевых товарищей, с которыми сидел в окопах, ходил в атаку ${ }^{54}$. В Стамбуле, переживая унижение на чужбине, Войцеховский, как и многие из русских эмигрантов, приходил на берег моря, долго стоял на ветру, всматриваясь в синеватую даль, словно пытаясь разглядеть берег далекой Родины ${ }^{55}$.

Отмечается автором способность обустраивать то место, в котором на более продолжительное время оказывался герой его романа. Так, после изгнания красных из Челябинска налаживается жизнь в регионе: восстановлены органы местного самоуправления, введена свободная торговля продуктами, установлен контроль за городским хозяйством, проводилась противоэпидемическая работа, действовали около 50 учебных заведений, был открыт Народный университет. В Екатеринбурге актуальной оказалась борьба с грабежами и мародерством. Среди чехословаков были «строители и архитекторы, восстанавливающие разрушенные дома. [...] Легионеры одевали и кормили беспризорников. [...] Да, они стреляли и убивали, потому что в них тоже стреляли, их тоже убивали. Но ведь они не только стреляли. Они наводили порядок, защищали простых людей и даже, как могли, вносили вклад в развитие культуры и просвещения» ${ }^{56}$. Умение обустроить жизнь свойственно и русским эмигрантам. Лагерный доктор Смородин вспоминает: «И вот на пустом месте спустя каких-нибудь шесть-семь лет в Харбине возникла русская цивилизация. Мы строили прекрасные дома, прокладывали железные и шоссейные дороги» ${ }^{57}$, он упоминает о концертах и университетах, прекрасных русских школах. Войцеховский, оказавшись в Праге, был поражен обилием русских учебных заведений («русский Оксфорд»), блестящими именами ученых, писателей, артистов, священников, военных - благодаря поддержке президента Томаша Масарика, правительства и Карела Крамаржа ${ }^{58}$. Прага стала для Войцеховского новой родиной, которую он готов был защищать. В 1923 г. он был назначен в словацкий город Трнаву, в 1927 г. его дивизия была признана лучшей, он был переведен командующим в Брненский военный округ, где под его

\footnotetext{
54 Ibid., 39.

55 Ibid., s. 42.

56 Ibid., s. 29-30.

57 Ibid., s. 20.

58 Ibid., s. 45 .
} 
началом возводились мощные оборонительные укрепления, осенью 1935 принял командование Пражским округом.

Особенность Войцеховского в изображении Каржавина - острое чувство личной вины за исторические события. Гражданская война началась летом 1918 с чехословацко-венгерского инцидента под Челябинском. Тогда именно Войцеховский принял решение не отправлять эшелон дальше, а идти освобождать своих незаконно арестованных солдат и офицеров, что привело к столкновению с красными; впрочем, он понимает, что Гражданская война все равно началась бы. Особенно мучают его два опоздания. Летом 1918, взяв Курган и Шадринск, он направил войска на Тюмень и опоздал на 10 дней в Екатеринбург, где была расстреляна царская семья ${ }^{59}$. Во второй раз он не сумел предотвратить Вторую мировую войну. 30 сентября 1938 года им было принято решение арестовать президента Бенеша, согласившегося с требованием Гитлера передать Германии Судетскую область. Но ситуация так сложилась, что шанс был упущен ${ }^{60}$.

Роман Каржавина сопровождает авторский комментарий, в котором доказывается, что у Германии не было шансов захватить Чехословакию или её часть. Если бы Войцеховский исполнил задуманное, войны бы не было, мировая история пошла бы по другому пути. «Для этого нужно было не так уж много чтобы генерал Войцеховский решился на арест президента Бенеша. Он не решился. Очень жаль, что не решился» ${ }^{61}$.

Чехословакия снова столкнулась с набиравшей силу империей - Третьим рейхом. Роман Каржавина имеет кольцевую композицию: в начале мы видим Войцеховского умирающим в сталинском лагере, в конце сообщается о его смерти. Незадолго до кончины ему довелось увидеться с Брусницыным, бывшим молодым красноармейцем, возражавшим тогда, в 1918 г. в Челябинске, против ареста чехословаков. Генерал Брусницын рассказал, что члены челябинского совета плохо кончили: комиссар Бершадский был расстрелян в 1937 г. как троцкист и враг народа, матрос Сибиряков убит в Кронштадте во время мятежа против советской власти. У самого Брусницына погибли в войну сын и жена. Некогда бывшие идейные враги оказались жертвами системы, не считающейся с интересами отдельного человека.

Таким образом, отталкивание от легионеров как от «чужих» и «интервентов» сменяется интересом к частным судьбам и желанием разобраться в мотивах поступков. Идея «третьего пути», довольно внятно звучащая в ряде исторических трудов постсоветского времени, также тесно переплетена с деятельностью

\footnotetext{
59 Ibid., s. 29

60 Ibid., s. 69.

61 Ibid., s. 77.
} 
чехословацких легионеров. Определенный вклад в современную «постпамять» внесла попытка областной автономии на демократической основе, поддержанная чехословацкими легионерами. Именно их защита обеспечила, пусть и на короткий срок, существование Уральского областного правительства. Как видим, строго идеологический критерий оценок обобщенных «красных», или

\section{About the author}

Nina Vladimirovna Barkovskaya, Urals State Pedagogical University, Institute of Philology, Culturology and Inter-Cultural Communication, Department of Literature and Teaching of Literature, Ekaterinburg, Russia,n_barkovskaya@list.ru 
